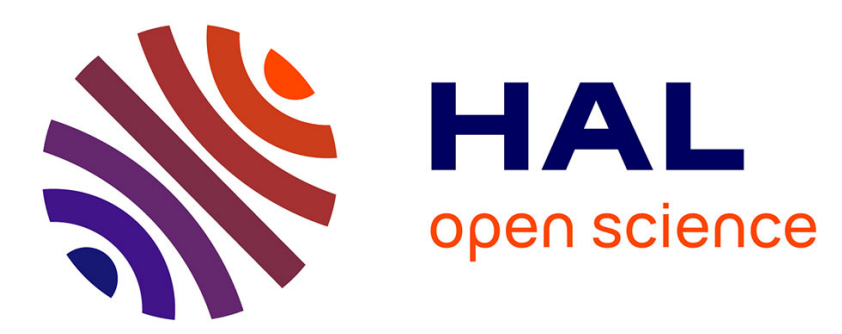

\title{
A modeling approach to the impact of HIV mutations on the immune system
}

Elisabeta Vergu, J.L. Golmard, A. Mallet

\section{To cite this version:}

Elisabeta Vergu, J.L. Golmard, A. Mallet. A modeling approach to the impact of HIV mutations on the immune system. Stochastic Modelling in Population Dynamics, Apr 2007, Luminy, France. hal-02754323

\section{HAL Id: hal-02754323 \\ https://hal.inrae.fr/hal-02754323}

Submitted on 3 Jun 2020

HAL is a multi-disciplinary open access archive for the deposit and dissemination of scientific research documents, whether they are published or not. The documents may come from teaching and research institutions in France or abroad, or from public or private research centers.
L'archive ouverte pluridisciplinaire HAL, est destinée au dépôt et à la diffusion de documents scientifiques de niveau recherche, publiés ou non, émanant des établissements d'enseignement et de recherche français ou étrangers, des laboratoires publics ou privés. 


\title{
A modeling approach to the impact of HIV mutations on the immune system
}

\author{
Elisabeta Vergu ${ }^{1}$ (with JL Golmard ${ }^{2}$ and A Mallet ${ }^{2}$ ) \\ ${ }^{1}$ UR341 INRA MIA F78352 Jouy-en-Josas, France, \\ elisabeta.vergu@jouy.inra.fr \\ ${ }^{2}$ Biomathématique et Informatique Médicale, Université Paris 6, France
}

A dynamical system modeling the intra-host HIV infection, coupled with a stochastic process for the mutation occurrence is used, after simplifications, to study the impact of the viral diversity on the disease dynamics. A new state function, having a biological interpretation as immunological recognition efficacy (IRE) index is defined. The existence and the stability of the endemically infected steady state of the IRE index-based model, as function of this index, are studied. It is also shown that the IRE index-based model provides bounds to the responses of the initial complex dynamical system. The biological interpretation of these mathematical results is the exhaustion of the immune system as a consequence of the continuous generation of viral mutants. 